Volume 1 Issue 2, July-December 2020: pp. 149-162.

Faculty of Law, Universitas Lampung, Bandar Lampung, Indonesia. http://jurnal.fh.unila.ac.id/index.php/ip

P-ISSN: 2723-2638

E-ISSN: $2745-9314$

\title{
Faktor-Faktor Kejahatan Pembunuhan Berencana Yang Dilakukan Oleh Anak Terhadap Anak
}

\section{The Crime Factors of Premeditated Murder Committed by Children Against Children}

\author{
Yogi Aranda \\ ogiarnda@gmail.com
}

Jaksa

Submitted: August 3, 2020; Reviewed: August 19, 2020; Accepted: Sep 182020

Info Artikel

Abstrak

Kata Kunci: Kejahatan; Pembunuhan Berencana; Anak.

Keywords: Crime; Planned Kills; Child.

DOI:

https://doi.org/10.25041/ip.vli2.2065
Kejahatan pembunuhan berencana oleh anak yang masih di bawah umur terhadap teman sebayanya sendiri merupakan suatu hal yang sangat kejam. Rumusan permasalahan dalam penelitian ini adalah apa yang menjadi penyebab dan bagaimana upaya penanggulangan terhadap kejahatan pembunuhan berencana dengan pelaku dan korban anak. Metode yang digunakan di dalam memecahkan permasalahan penelitian ini yaitu menggunakan pendekatan secara Yuridis Normatif dan Yuridis Empiris. Berdasarkan hasil penelitian dan pembahasan, maka dianalisis (1) Faktor penyebab terjadinya kejahatan pembunuhan berencana dengan pelaku dan korban anak yaitu: Rendahnya tingkat pendidikan dan nilai-nilai spiritual, Lingkungan yang tidak bersahabat (Keluarga, Sekolah dan Masyarakat), Perkembangan teknologi yang sangat pesat, Kemampuan ekonomi yang rendah. (2) Upaya dalam menanggulangi kejahatan pembunuhan berencana dengan pelaku dan korban anak yaitu upaya preventif: melakukan razia berupa senjata tajam, pengecekan identitas di tempat hiburan 
malam, melakukan penyuluhan hukum ke sekolah-sekolah serta penyuluhan hukum berupa dialog interaktif melalui media elektronik radio dan upaya represif: menitikberatkan pada proses peradilan sesuai dengan ketentuan yang tertera di dalam UndangUndang Nomor 11 Tahun 2012 tentang Sistem Peradilan Pidana Anak. Saran dalam penelitian ini adalah, diharapkan Hakim dalam memutuskan perkara anak pelaku kejahatan pembunuhan tidak semata-mata menggunakan sarana pemidanaan. Hakim harus mengutamakan perlindungan anak dan harus lebih bijaksana melihat keterlibatan anak, apakah anak sebagai pelaku atau ikut serta, sehingga diharapkan hakim dapat memberikan sarana diluar pemidanaan terhadap anak pelaku kejahatan pembunuhan, sebaiknya penegak hukum dalam melaksanakan penegakan hukum terhadap anak pelaku kejahatan pembunuhan berencana harus saling berkoordinasi dan lebih mengutamakan hak-hak anak. Aparat penegak hukum harus memberikan rasa nyaman kepada anak pelaku tindak pidana, agar dapat memperbaiki kepribadian anak dimasa yang akan datang, dioptimalkan lagi penyuluhan dan sosialisasi oleh perangkat daerah dan kota ke sekolah-sekolah dan desa-desa agar dapat menambah pengetahuan warga masyarakat terkait dampak dari melakukan suatu tindak pidana.

\section{Abstract}

The crime of premeditated murder by minors against their own peers is a very cruel thing. The formulation of the problem in this study is what is the cause and how to deal with the crime of premeditated murder with child offenders and victims. The method used in solving the problem of this research is to use a Normative Juridical and Empirical Juridical approach. Based on the results of research and discussion, it is analyzed (1) Factors that cause the crime of premeditated murder with child offenders and victims, namely: Low levels of education and spiritual values, a hostile environment (Family, School and Society), Rapid technological development, Low economic ability. (2) Efforts in overcoming 
the crime of premeditated murder with child offenders and victims are preventive measures: conducting raids in the form of sharp weapons, checking identity in nightclubs, conducting legal counseling to schools and legal counseling in the form of interactive dialogue through electronic radio media and efforts Repressive: focuses on the judicial process in accordance with the provisions contained in Act Number 11 of 2012 concerning the Criminal Justice System for Children. The suggestion in this research is that it is expected that the Judges in deciding the case of a child who committed a murder crime does not merely use the means of punishment. Judges must prioritize child protection and must be more prudent in seeing the involvement of children, whether children are perpetrators or participating, so that judges are expected to provide facilities beyond the punishment of children who commit murder crimes, it is better for law enforcers to carry out law enforcement against children who commit premeditated murder must be mutually coordinate and prioritize children's rights. Law enforcement officials must provide comfort to children who commit crime, in order to improve the personality of children in the future, to further optimize counseling and dissemination by regional and municipal officials to schools and villages in order to increase the knowledge of citizens related to the impact of the community. commit a crime.

\section{A. Pendahuluan}

Pada dasarnya hukum adalah pencerminan dari HAM, sehingga hukum itu mengandung keadilan atau tidak akan ditentukan oleh Hak Asasi Manusia yang terkandung dan juga diatur atau dijamin dalam hukum tersebut. Hukum tidak akan lagi dilihat sebagai cerminan dari kekuasaan semata-mata, namun juga harus mencerminkan perlindungan terhadap hak-hak para warga negara. ${ }^{1}$ Pada era milenial saat ini manusia seringkali dihadapkan pada suatu kebutuhan yang mendesak, yang dianggap sebagai kebutuhan pemuas diri. Pada dasarnya kebutuhan tersebut hanyalah sebagai sarana untuk mempertegas status sosial di dalam kehidupan bermasyarakat. Wujud pemenuhan kebutuhan eksistensi tersebut biasanya dilakukan tanpa pemikiran yang matang, sehingga mereka akan melakukan apapun meskipun hal tersebut merupakan suatu penyimpangan yang merugikan dan tidak bisa diterima oleh lingkungan dan

\footnotetext{
${ }^{1}$ Eka Intan et al., "Begal Anak; Pemenuhan Hak Dan Lembaga Pembinaan Khusus Anak Kelas Ii A Bandar Lampung Fulfillment Of The Rights Of The Child In The Class Ii Special Child Coaching Institution In Bandar Lampung," Cepalo Vol.2, no. 2 (September 12, 2018): 45-84, https://doi.org/10.25041/cepalo.v2no2.1764. hlm 76.
} 
sesama manusia. Perilaku menyimpang remaja merupakan masalah sosial yang sering muncul di Indonesia dalam berbagai bentuk dan sudah dianggap sebagai masalah yang cukup mengkhawatirkan. ${ }^{2}$

Secara sosiologis seseorang yang melakukan tindak pidana kejahatan merupakan hasil perubahan-perubahan sosial dan budaya dalam masyarakat sebagai bentuk deviasi sosial (pelanggaran norma-norma masyarakat). ${ }^{3}$ Penyebab yang ditimbulkan oleh hal-hal yang menyimpang inilah yang membuat kehidupan sosial masyarakat menjadi tidak selaras, diperlukan suatu pertanggungjawaban dari pelaku yang menciptakan ketidakseimbangan supaya dapat dirasakan juga penderitaan atau kerugian yang dialami oleh seseorang atau kelompok yang menjadi korban. ${ }^{4}$ Berat ringannya hukuman yang wajib dijalankan oleh seseorang untuk mempertanggungjawabkan perbuatannya tergantung dari penilaian masyarakat terhadap suatu perbuatan baik atau tidak sesuai dengan ukuran rasa keadilan dan kepentingan umum. ${ }^{5}$ Maraknya kasus kejahatan di Indonesia saat ini sering mendominasi berita harian di berbagai media massa. Berbagai kasus tersebut ditangani pihak yang berwenang, untuk mencari akar persoalan alasan seseorang melakukan kejahatan. ${ }^{6}$ Anak dibawah umur sekarang ini banyak yang melakukan tindak pidana, yang perlu ditangani dengan seksama melalui sistem peradilan pidana anak. ${ }^{7}$ Setiap anak memiliki lingkungan yang berbeda-beda serta latar belakang ekonomi yang berbedabeda, pergaulan, keluarga, pendidikan, dan seterusnya. ${ }^{8}$

Pada kenyataannya di dalam kehidupan bermasyarakat saat ini seringkali terjadi penyimpangan terhadap norma perilaku khususnya norma hukum yang biasa disebut dengan kejahatan. Kejahatan yang biasanya dilakukan oleh orang yang sudah dewasa, di era industri 4.0 ini kejahatan serupa juga dilakukan oleh anak yang masih di bawah umur, terlebih kejahatan yang dilakukan merupakan kejahatan yang tidak semestinya dilakukan oleh seseorang yang masih dalam perlindungan hukum seperti kejahatan pembunuhan berencana. Kenyataan tersebut sungguh memprihatinkan, yang mana dalam Undang-Undang Nomor 3 tahun 1997 anak merupakan bagian dari generasi muda sebagai salah satu sumber daya manusia yang merupakan potensi serta penerus cita-cita perjuangan bangsa, yang memiliki peranan strategis serta mempunyai ciri dan sifat khusus, memerlukan pembinaan dan perlindungan dalam rangka menjamin pertumbuhan dan perkembangan fisik, mental dan sosial secara utuh, serasi, selaras juga seimbang. ${ }^{9}$ Setiap anak yang dilahirkan adalah suci,maka orang tua dan lingkunganlah

\footnotetext{
2 Sigit Hardiyanto et al., "Remaja Dan Perilaku Menyimpang (Studi Kasus Remaja Di Kota Padangsidimpuan)," Jurnal Interaksi: Jurnal Ilmu Komunikasi, vol. $2, \quad$ No. 1 (March 13 2018): 23-32, http://jurnal.umsu.ac.id/index.php/interaksi/article/view/1785. hlm 23.

${ }^{3}$ Djesi Ariani, "Pertanggungjawaban Pelaku Tindak Pidana Pembunuhan Berencana Yang Dilakukan Oleh Anak (Studi Putusan Pengadilan Negeri Nomor 16/Pid.Sus-Anak/2016/PN.Cbn)." Jurnal Hukum Kaidah: Media Komunikasi Dan Informasi Hukum Dan Masyarakat, Vol. 19, No. 2 (2020): 114-136, https://jurnal.uisu.ac.id/index.php/jhk/article/view/2334/1571. hlm 115 .

${ }^{4}$ R. Abdoel Djamali, Pengantar Hukum Indonesia, Depok: PT. RajaGrafindo Persada, 2019, hlm. 171

${ }^{5}$ Ibid, hlm. 172 .

${ }^{6}$ Maharani, "Manusia Sebagai Homo Economicus: Refleksi Atas Kasus-Kasus Kejahatan Di Indonesia." Jurnal Filsafat," Jurnal Filsafat, Vol. 26, No. 1 (Februari 2016):31-52, https://dev.jurnal.ugm.ac.id/wisdom/article/view/12624/9083. hlm 31.

${ }^{7}$ Anselmus S. J. Mandagie, "Proses Hukum Tindak Pidana Pembunuhan Yang Dilakukan Oleh Anak Dibawah Umur Ditinjau Dari Undang-Undang Nomor 11 Tahun 2012 Tentang Sistem Peradilan Pidana Anak,” LEX CRIMEN, vol. 9, No. 2 (May 18, 2020): 53-62, https://ejournal.unsrat.ac.id/index.php/lexcrimen/article/view/28552. hlm 53.

${ }^{8}$ Shofwatal Qolbiyyah, "Kenakalan Remaja (Analisis Tentang Faktor Penyebab Dan Solusinya Dalam Perspektif Pendidikan Agama Islam)." Sumbula: Jurnal Studi Keagamaan, Sosial Dan Budaya, Vol. 2, No. 1, (Januari-Juni 2017):493-512 http://ejournal.kopertais4.or.id/mataraman/index.php/sumbula/article/view/2984. hlm 493.

${ }^{9}$ R. Wiyoni, S.H, Sistem Peradilan Pidana Anak, Jakarta: Sinar Grafika,2018, hlm. 3.
} 
yang akan membentuk karakternya, baik atau puntidak baik tergantung bagaimana didikan orang tua dan lingkungan dimana dia tinggal. ${ }^{10}$

Melenyapkan jiwa individu lain dengan terencana dalam (KUHP) merupakan suatu pembunuhan. Kejahatan pembunuhan pada dasarnya tidak mengenal gender, siapapun orangnya baik laki-laki dan perempuan bisa menjadi pelaku. ${ }^{11}$ Akan tetapi pembunuhan yang dilakukan oleh anak ini menarik untuk dikaji, hampir semua pembunuhan berasal dari suatu bentuk penyerangan berat yang pada umumnya dipandang sebagai kejahatan paling serius. Disamping itu pembunuhan adalah jenis kejahatan yang oleh publik, media dampolisi diberi prioritas tinggi untuk diselesaikan. ${ }^{12}$ Kejahatan pembunuhan adalah suatu kejahatan yang dengan sengaja maupun tidak merampas nyawa orang lain. Di dalam Pasal 338 KUHP menjelaskan tentang suatu pembunuhan biasa yang terdapat unsur-unsur pidana yaitu dengan sengaja yang berarti tindakan dan objeknya dimana hilangnya nyawa seseorang menjadi suatu hal yang dikehendaki oleh pelaku. Sedangkan apabila perbuatan yang dilakukan tidak setelah timbulnya niat melakukan pembunuhan atau pikir-pikir melalui perencanaan diatur di dalam Pasal 340 KUHP. ${ }^{13}$ Delik yang digunakan dalam kasus pembunuhan adalah delik materiil dimana suatu perbuatan itu dilakukan dengan sengaja menghilangkan nyawa orang lain. Perumusannya menitikberatkan kepada akibat yang dilarang dan diancam dengan pidana oleh undang-undang, dengan kata lain hanya disebut rumusan dari akibat perbuatannya. ${ }^{14}$

Tindak pidana pembunuhan pada dasarnya telah mengalami improvisasi seperti mutilasi, pembunuhan disertai dengan perampokan atau disertai dengan kasus pemerkosaan, dan pembunuhan yang dilakukan karena emosional. ${ }^{15}$ Pasal 340 KUHP adalah kejahatan pembunuhan berencana dimana terdapat jeda waktu yang cukup lama dalam pelaksanaannya sejak adanya niat yang timbul atau kehendak untuk melakukan pembunuhan. Waktu yang cukup lama tersebut digunakan oleh pelaku untuk memikirkan hal-hal yang memudahkannya melakukan kejahatan pembunuhan seperti misalnya apakah perbuatan tersebut harus dilakukan dan bagaimana cara melakukannya. Kemudian pelaku dalam memutuskan kehendaknya harus dengan suasana batin yang tenang, tidak terburu-buru atau dengan emosi tinggi begitu juga ketika melakukan perbuatan pembunuhan tersebut.

Kejahatan pembunuhan berencana adalah kejahatan yang paling berat ancaman pidananya dari seluruh bentuk kejahatan terhadap tubuh dan nyawa manusia yaitu hukuman maksimal pidana mati, selain itu kejahatan pembunuhan berencana ini juga diancam dengan pidana seumur hidup atau selama waktu tertentu paling lama dua puluh tahun. Pembunuhan atau menghilangkan nyawa seseorang baik secara sengajamaupun tidak sengaja, dibedakan antara konsep yuridis, yaitu sebagai perbuatan yang dilarang oleh undang-undang pidana, dan sebagai konsep sosiologis dan atau psikologis yang sering disebut dengan istilah perilaku

\footnotetext{
${ }^{10}$ Rahul Ardian Fikri, "Analisis Yuridis Terhadap Tindak Pidana Pembunuhan Berencana Yang Dilakukan Oleh Anak Dibawah Umur Menurut Undang-Undang Nomor 11 Tahun 2012 Tentang Sistem Peradilan Anak." Jurnal Abdi Ilmu, Vol. 1 No. 1 (Juni 2018): 158-168, http://jurnal.pancabudi.ac.id/index.php/abdiilmu/article/view/388. hlm 159.

${ }^{11}$ Shinta Dewi Rismawati, “Karakteristik Kejahatan Pembunuhan Dalam Konstalasi Relasi Gender," JURNAL PENELITIAN, vol. 5, No. 1 (May 21, 2013): 1-11, https://doi.org/10.28918/JUPE.V5I1.237. hlm 1.

${ }^{12}$ Frank E. Hagan, Pengantar Kriminologi, Jakarta: Kencana, 2013, hlm. 313

${ }_{13}$ Jesica Ribka Buluran, "Penerapan Sanksi Pidana Terhadap Pelaku Kejahatan Mutilasi Menurut Pasal 340 Kuhp," LEX ET $\begin{array}{lllllll}\text { SOCIETATIS, } & \text { vol. } & 5, & \text { No. } & 7 & \text { (December } & 5,\end{array}$ https://ejournal.unsrat.ac.id/index.php/lexetsocietatis/article/view/18098. hlm 130.

14 Gusti Ayu et al., "Perlindungan Hukum Terhadap Korban Tindak Pidana Penyalahgunaan Narkotika Di Kabupaten Buleleng," Junal Komunitas Yustitia, vol. 2, No. 1 (February 28, 2019): 1-11, https://ejournal.undiksha.ac.id/index.php/jatayu/article/view/23924. hlm 3.

15 Elton Mayo, "Kajian Yuridis Terhadap Tindak Pidana Pembunuhan Yang Dilakukan Oleh Anak,” Diponegoro Law Journal, vol. 3, No. 2 (Program Studi S1 Ilmu Hukum, Fakultas Hukum, Universitas Diponegoro, April 1, 2014): 1-12, http://ejournals1.undip.ac.id/index.php/dlr. hlm 4.
} 
menyimpang. ${ }^{16}$ Unsur-unsur di dalam Pasal 340 KUHP sama dengan Pasal 338 KUHP, hanya ditambah unsur dengan rencana terlebih dahulu. Pembunuhan tidak hanya orang dewasa saja yang dapat melakukan pembunuhan, akan tetapi anak-anak di bawah umur pun juga dapat melakukan hal yang sama. ${ }^{17}$

Banyaknya kasus pembunuhan biasa ataupun pembunuhan berencana yang terjadi di Indonesia dengan pelaku dan korban anak adalah hal yang sangat memprihatinkan, hal ini dapat diketahui melaui media massa baik elektronik maupun cetak. Namun, pertanggungjawaban pidana anak tidaklah cukup jika hanya didasarkan pada hukum materiil seperti KUHP, karena ketentuan dalam KUHP hukumnya bersifat konvensional yang mengacu kepada kepentingan hukum kolonial. ${ }^{18}$ Sebagian perkara pembunuhan yang terjadi saat ini unsur yang memicunya adalah adanya ketimpangan sosial dan ekonomi, dendam, lingkungan tidak bersahabat serta aspek yang timbul dalam perspektif psikologis. Perbuatan tersebut bertentangan dengan ketentuan Undang-Undang Dasar 1945 bahwa setiap orang berhak untuk hidup serta berhak mempertahankan hidup dan kehidupannya.

Kejahatan pembunuhan berencana dengan berbagai motif yang dilakukan oleh anak di bawah umur merupakan hal yang tidak lazim. Hal ini diakibatkan oleh peran orang tua di dalam keluarga yang tidak berfungsi dengan baik, kurangnya pendidikan budi pekerti, akhlak dan agama sehingga tidak ada lagi rasa welas asih terhadap sesama manusia. Pertanggungjawaban pidana wajib didapatkan pelaku kejahatan sebagai wujud dari sanksi hukum pidana yang dirasa adil oleh masyarakat. Anak yang melakukan tindak pidana/kejahatan (juvenile offender) jangan dipandang sebagai seorang penjahat (criminal), tetapi harus dilihat sebagai orang yang memerlukan bantuan,pengertian dan kasih sayang. ${ }^{19}$ Pada umumnya anak yang masih dibawah umur belum mampu membedakan mana perbuatan yang melanggar hukum dan mana dan mana perbuatan yang sesuai dengan aturan hukum. ${ }^{20}$

\section{B. Hasil Penelitian Dan Pembahasan}

\section{Faktor Terjadinya Kejahatan Pembunuhan Berencana Dengan Pelaku Dan Korban Anak}

Menurut Irma Gustiana A, Psikolog anak dan remaja menyatakan bahwa ada berbagai macam faktor anak bertindak kriminal yang salah satunya adalah kurangnya kasih sayang dari orang tua sehingga anak melakukan pemuasan Psikologis di luar. Selain itu, stressor sosial ekonomi atau keluarga yang punya ekonomi rendah, disorganisasi sosial atau kurangnya pengendalian diri dalam reaksi agresi, lingkungan sosial dengan kekerasan tinggi atau mengalami kekacauan sosial serta kurang memiliki nilai dan norma yang berlaku dalam keluarga juga dapat membentuk karakter pada diri anak, banyaknya aktivitas kurang baik yang ditayangkan melalui media sosial dan internet yang secara tidak langsung membuat anak-anak tidak sadar dan menganggap perilaku yang mereka lakukan adalah hal normal, selanjutnya

\footnotetext{
${ }^{16}$ Akhmad Syarifudin, “Tinjauan Yuridis Terhadap Tindak Pidana Pembunuhan Berencana,” Dinamika: Jurnal Ilmiah Ilmu Hukum, vol. 25, No.14 (July 29, 2019): 1-5, http://www.riset.unisma.ac.id/index.php/jdh/article/view/4210. hlm 3.

${ }_{17}$ Arinal Maftukh Alifah et al., "Dinamika Psikologis Narapidana Anak Pelaku Pembunuhan: Studi Kasus Di Lapas Anak Kutoarjo," Indigenous: Jurnal Ilmiah Psikologi, Vol. 13, no. 2 (October 12, 2016): 9-18, http://journals.ums.ac.id/index.php/indigenous/article/view/2600. hlm 10.

${ }^{18}$ Syamsiar Arief, "Tinjauan Yuridis Terhadap Tindak Pidana Pembunuhan Berencana Yang Dilakukan Oleh Anak," Petitum, Vol. 4, No. 1 (1 April 2016): 65-72, https://uit.e-journal.id/JPetitum/article/view/451/322. hlm 67.
}

${ }^{20}$ Agus Bambang Nugraha, "Pembunuhan Berencana Oleh Anak Di Bawah Umur," JGK (Jurnal Guru Kita,) Vol. 3, no. 2 (March 20, 2019): 144-57, https://jurnal.unimed.ac.id/2012/index.php/jgkp/article/view/14781. hlm 145. 
faktor terakhir dan yang terpenting adalah tidak adanya nilai spiritual yang baik yang seharusnya tertanam dalam diri seorang anak sejak masih dini. ${ }^{21}$

Kemudian menurut Toni Fiser dari Komnas Perlindungan Anak Provinsi Lampung mengatakan bahwa KPAI pada tahun 2018 mengadakan riset terkait anak sebagai pelaku kejahatan yang mana dalam kurun waktu 7 tujuh tahun terakhir kasus anak yang berhadapan dengan hukum baik sebagai pelaku maupun sebagai korban menjadi kasus tertinggi dengan jumlah mencapai 9.266 (sembilan ribu dua ratus enam puluh enam) kasus, yang mana sebagian besar kasus kejahatan oleh anak terutama pembunuhan, korbannya adalah teman akrab dan teman main pelaku. Menurutnya salah satu penyebab peristiwa ini terjadi tidak terlepas dari pengaruh media yang memberikan contoh tidak baik melalui tayangan dan juga dalam bentuk games bernuansa kekerasan yang kemudian berpengaruh terhadap perilaku anak. Selain itu faktor lingkungan yang tidak bersahabat, pengaruh teman serta kebebasan yang berlebihan juga merupakan faktor-faktor yang mendorong anak melakukan kejahatan. ${ }^{22}$

Selanjutnya menurut Akademisi Hukum dari Universitas Pamulang Gregorius Hermawan $\mathrm{K}$, mengatakan bahwa yang menjadi penyebab terjadinya kejahatan pembunuhan berencana dengan pelaku dan korban anak yang pertama adalah faktor kesalahpahaman. Kesalahpahaman sering kali diawali dengan kurangnya komunikasi dan penjelasan antara satu dengan lainnya. Kesalahpahaman biasanya terjadi karena ego yang sangat tinggi dari setiap individu sehingga menimbulkan masalah yang memicu terjadinya tindak pidana. Kemudian yang kedua faktor emosi yang labil, anak pada masa remaja merupakan masa yang sangat labil emosinya. Memiliki emosi yang labil dalam menangkap informasi dan ingin mewujudkan keinginan hati seringkali tanpa berfikir dahulu apakah perbuatan yang dilakukannya merupakan perbuatan yang baik atau buruk dan dampak yang akan ditimbulkan dari suatu perbuatan tersebut dapat merugikan diri sendiri maupun orang lain. Faktor yang ketiga adalah rendahnya budi pekerti, faktor ini menyebabkan pelaku kejahatan tidak dapat berfikir dengan menggunakan akal budinya ketika melakukan kejahatan. Rendahnya budi pekerti yang dialami oleh kelompok anak disebabkan karena kurangnya kontrol sosial dalam lingkungan keluarga maupun sekolah. Selanjutnya faktor yang terakhir adalah rendahnya iman, faktor ini merupakan faktor yang mendasar menyebabkan terjadinya kejahatan. Keyakinan serta pengetahuan agama yang kurang akan membuat seseorang tidak memiliki iman yang kuat. Orang yang imannya lemah cenderung mudah terpancing emosinya untuk melakukan kejahatan. ${ }^{23}$

Berdasarkan pendapat para responden diatas, terdapat beberapa teori yang sejalan dari para ahli kriminologi yang dipergunakan untuk mempelajari sebab-sebab terjadinya kejahatan. Kejahatan memiliki keterkaitan dengan kondisi individu pelaku, dimana terdapat teori-teori yang mengemukakan variabel mengapa individu berperilaku jahat yaitu: ${ }^{24}$

\section{a. Teori Klasik}

Teori ini dalam kriminologi menunjuk pada sebuah pendekatan yang menekankan kehendak bebas dan rasionalitas aktor kriminal. Sebelum formulasi dan diterimanya teori klasi, pelaksanaan peradilan pidana di Eropa tidak bisa diperkirakan, tidak menentu dan kejam. Pada awal abad ke-19 terdapat 100 lebih kejahatan yang dapat dijatuhi hukuman mati. Kebijakan pidana dirancang untuk mengontrol "kelas-kelas berbahaya", masa tanpa properti petani, pekerja dan pengangguran. Kemunculan filsafat liberal yang dianut para penulis seperti Locke,

\footnotetext{
${ }^{21}$ Wawancara dengan Irma Gustiana A selaku Psikolog anak dan remaja pada Biro Psikologi Ruang Tumbuh, Tanggal 3 September 2019

${ }^{22}$ Wawancara dengan Toni Fiser selaku Komnas Perlindungan Anak Provinsi Lampung, Tanggal 23 Agustus 2019

${ }^{23}$ Wawancara dengan Dr. Gregorius Hermawan K, S.H., M.H selaku akademisi Universitas Pamulang dan Widya Iswara pada Badan Diklat Kejaksaan RI, Tanggal 5 September 2019.

${ }^{24}$ Topo santoso dan Eva Achjani Zulfa, Kriminologi, Jakarta: RajaGrafindo Persada, 2011, hal. 25
} 
Hobbes dan Rousseau mengusung "hak-hak alami manusia" dan rasio sebagai panduan dalam mengatur tindak tanduk manusia. ${ }^{25}$

\section{b. Teori Neo Klasik}

Teori neoklasik pada dasarnya mengakui keadaan lingkungan, psikologis dan keadaan meringankan lainnya sebagai kondisi-kondisi yang memodifikasi doktrin klasik. Poin kunci dari teori ini adalah bahwa kita tidak perlu mempunyai penjelasan dasar penyebab atau menunggu penjelasan tersebut untuk memenuhi kebutuhan mendesak kebijakan yang tidak bisa menunggu penjelasan final. Dalam teori ini mengemukakan bahwa pelaku menimbang peluang, biaya dan manfaat kejahatan tertentu. Sistem peradilan pidana harus menjadikan kejahatan kurang menguntungkan dengan meningkatkan kepastian dan beratnya hukuman. ${ }^{26}$

c. Teori Ekologis

Teori ini biasa disebut juga sebagai mazhab statistik, geografi atau kartografi. Ekologi adalah cabang biologi yang membahas hubungan timbal balik antara organisme dan lingkungan mereka. Ekologi manusia membicarakan hubungan timbal balik antara organisme manusia dan lingkungan fisik. Disebut mazhab statistik karena mazhab inilah yang pertama kali berupaya menerapkan data resmi dan statistik bagi problem dalam menjelaskan kriminalitas. Label geografi dan kartografi disandangkan karena penulis dalam kelompok ini cenderung bersandar pada peta dan data foto udara dalam penelitian mereka. ${ }^{27}$

d. Teori Sosialis

Teori sosialis merupakan teori yang memiliki tiga unsur pengelompokkan diantaranya Anomie, penyimpangan budaya dan kontrol sosial. Para ahli dalam teori Anomie memandang kejahatan sebagai gelaja sosial yang disebabkan oleh struktur sosial yang mengalami perubahan sehingga seseorang tidak mampu beradaptasi dengan lingkungannya. ${ }^{28}$ Sedangkan dalam teori penyimpangan budaya, kejahatan dianggap sebagai seperangkat nilai-nilai yang khas pada lower class. $^{29}$ Kemudian untuk teori kontrol sosial, kejahatan dikaitkan dengan variabelvariabel yang bersifat sosiologis, antara lain struktur lembaga, pendidikan dan kelompok dominan. ${ }^{30}$

e. Teori Biologis

Pendekatan bilogis atas sebab kejahatan memandang pelaku kejahatan secara mandiri pada "individunya" semata sebagai pembuat kejahatan. Teori-teori tersebut ada yang menitikberatkan pada kejahatan yang disebabkan oleh faktor gen, ada pula yang mengambil kesimpulan tipe-tipe kejahatan yang dapat diidentifikasi berdasarkan ciri-ciri fisik yang melekat pada pelaku kejahatan. Teori-teori tersebut diantaranya:

f. Teori Lahir Sebagai Penjahat (Born Crimina)l

Teori ini merupakan teori yang dibawa oleh Cesare Lombroso (1835-1909). Teori ini menjelaskan bahwa penjahat mewakili suatu tipe keanehan atau keganjilan fisik yang berbeda dengan non-kriminal. Lombrosso menyatakan bahwa penjahat memiliki suatu bentuk kemerosotan yang termanifestasikan dalam karakter fisik yang merefleksikan suatu bentuk awal dari evolusi. ${ }^{31}$ Teori ini dianggap sederhana dan naif untuk saat ini, namun teori ini berjasa dalam penelitian mengenai kejahatan dan mengalihkan studi tentang kejahatan dari penjelasan

\footnotetext{
${ }^{25}$ Frank E. Hagan, Op.Cit, hlm. 136.

${ }^{26}$ Frank E. Hagan, Op.Cit, hlm. 142.

${ }^{27}$ Frank E. Hagan, Op.Cit, hlm. 146.

${ }^{28}$ Muhammad Mustofa, Metodologi Penelitian Kriminologi, Jakarta: Kencana, 2013, hlm. 62.

${ }^{29} \mathrm{Ibid}$, hlm. 69.

${ }^{30} \mathrm{Ibid}$, hlm. 76.

${ }^{31}$ Prof. Dr. A. S. Alam, S.H., M.H dan Dr. Amir Ilyas, S.H., M.H, Kriminologi Suatu Pengantar, Jakarta: Kencana, 2018, Hlm. 51
} 
abstrak, metafisik, legal dan juristik sebagai basis penghukuman menuju suatu studi ilmiah tentang penjahat serta kondisi-kondisi pada saat dia melakukan kejahatan. ${ }^{32}$

\section{g. Teori Fisik}

Teori ini merupakan teori kriminologi dengan dasar pengujian identifikasinya adalah fisik seperti bentuk tubuh, tinggi badan, berat badan, bentuk wajah dan lain semua yang terdapat dalam fisik manusia. ${ }^{33}$

h. Teori Disfungsi otak dan Learning Disabilities

Teori ini adalah teori yang dibuat dengan mengubah jaringan otak untuk mengubah kepribadian atau perilaku agar seseorang tersebut lebih bisa dikontrol. Teori ini merupakan sebuah langkah terakhir dalam pendekatan bedah biomedis terhadap kriminalitas, namun walaupun dapat diterapkan dalam kasus khusus yang langka teori ini tidak menawarkan banyak sebagai solusi umum bagi problem kejahatan. ${ }^{34}$

i. Teori Faktor Genetik

Teori ini memandang kejahatan sebagaimana disebabkan oleh faktor genetik yang menyimpulkan kalau proses pembuahannya hingga dilahirkan mendapatkan pemeliharaan dan perawatan yang salah. Rata-rata peneliti menarik kesimpulan berdasarkan generalisasi dari sekian sampel pada kasus yang menunjukkan banyaknya kesamaan. ${ }^{35}$

j. Teori Lingkungan

Teori ini merupakan teori yang mengakui bahwa manusia memiliki akalnya disertai kehendak bebas untuk menentukan pilihannya, akan tetapi teori ini juga berpendapat bahwa kehendak mereka itu tidak terlepas dari pengaruh faktor lingkungannya. Teori ini berpegang teguh pada keyakinan bahwa seseorang dikuasai oleh hukum sebab akibat (cause-effect relationship). ${ }^{36}$

k. Teori Positivis

Positivisme adalah premis dasar yang berarti pengukuran (kuantifikasi), objektivitas (netralitas) dan kausalitas (determinisme). Teori ini menekankan pada sebuah pandangan dunia konsensus, sebuah fokus lebih pada aktor kriminal daripada perbuatan kriminal. ${ }^{37}$

\section{Upaya Yang Dilakukan Dalam Menanggulangi Kejahatan Pembunuhan Berencana Dengan Pelaku Dan Korban Anak}

Upaya penanggulangan dalam bentuk preventif maupun represif merupakan suatu cara atau kebijakan dalam menanggulangi suatu kejahatan. Kebijakan yang digunakan tidak hanya kebijakan yang bersifat represif atau melalui hukum pidana, melainkan juga kebijakan yang sifatnya preventif yaitu diluar hukum pidana. Kebijakan hukum pidana bukanlah semata-mata pekerjaan teknik perundang-undangan yang dapat dilakukan secara yuridis normatif dan sistematik dogmatik, tetapi juga memerlukan pendekatan yuridis faktual yang dapat berupa pendekatan sosiologi, historis dan komparatif, bahkan memerlukan pula pendekatan

\footnotetext{
${ }^{32}$ Ibid, hlm. 52

${ }^{33} \mathrm{Ibid}$, hlm. 53.

${ }^{34}$ Frank E. Hagan, Op.Cit, hlm.175.

${ }^{35} \mathrm{Ibid}$, hlm. 54.

${ }^{36} \mathrm{Ibid}$, hlm. 57.

${ }^{37}$ Frank E. Hagan, Op.Cit, hlm.162.
} 
komprehensif dari berbagai disiplin sosial lainnya dan pendekatan integral dengan kebijakan sosial dan pembangunan nasional pada umumnya. ${ }^{38}$

Menurut Penyidik E. Angelina Polres Lampung Selatan Upaya preventif yang dilakukan oleh Kepolisian adalah dengan cara mengadakan razia rutin untuk meminimalisir terjadinya kriminal, razia yang dilaksanakan berupa razia sajam (senjata tajam) dan pengecekan identitas di tempat hiburan malam, kemudian melakukan sosialisasi ke sekolah-sekolah dengan memberikan informasi akan bahaya tindakan kriminalitas yang dilakukan kelompok anak, pihak Polres Lampung Selatan juga mengajak seluruh elemen masyarakat untuk mencegah aksi kejahatan yang dilakukan oleh kelompok anak dengan cara langsung melaporkan kepada pihak Kepolisian apabila melihat langsung perbuatan anarkis yang dilakukan oleh kelompok anak, pihak Polres Lampung Selatan juga menghimbau kepada orang tua agar memberi tahu anakanak untuk mengurangi kegiatan yang dilakukan pada malam hari supaya tidak terjadi hal yang tidak dinginkan dan melakukan peningkatan pengamanan di wilayah hukum Polres Lampung Selatan. Sedangkan upaya represif yang dilakukan adalah dengan penegakan hukum terhadap kejahatan pembunuhan yang dilakukan oleh anak mengacu pada ketentuan undang-undang yang berlaku, baik menurut KUHP, UU No. 11 Tahun 2012 tentang SPPA, dan PP Nomor 65 tahun 2015 tentang Pelaksanaan Diversi dan Penanganan Anak Yang Belum 12 (dua belas) Tahun. KUHAP merupakan dasar bagi penegakan hukum pidana itu sendiri dimana mengatur bagaimana tata cara mengajukan suatu perkara pidana ke depan pengadilan. Pihak penyidik Polres Lampung Selatan lebih dahulu mengupayakan Diversi bagi anak yang berusia dibawah 18 tahun yang diduga melakukan tindak pidana. Diversi adalah upaya untuk menemukan kata sepakat antara kedua belah pihak yaitu antara pihak korban dan pelaku dan tidak ada perlawanan dari pihak manapun, apabila tidak terjadi kesepakatan maka pihak Kepolisian akan melanjutkan perkara tersebut dengan menyerahkannya kepada pihak Kejaksaan untuk dilanjutkan proses peradilan pidana.

Kemudian menurut Fransisca Jaksa Penuntut Umum dari Kejaksaan Negeri Lampung Selatan, upaya preventif yang dilakukan oleh Kejaksaan salah satunya adalah dengan program Jaksa Masuk Sekolah. Kegiatan Jaksa Masuk Sekolah ini sudah dilakukan di seluruh Indonesia dengan tujuan untuk memberikan informasi berupa penyuluhan hukum tentang produk hukum seperti undang-undang kepada siswa dan para guru agar lebih sadar hukum. Program ini merupakan salah satu metode andalan Kejaksaan Republik Indonesia sebagai bentuk upaya preventif terhadap penanggulangan kejahatan dalam rangka menciptakan anak-anak bangsa yang taat hukum sehingga kelak menjadi generasi penerus bangsa dan memiliki masa depan yang baik. Selain itu program lainnya yang menjadi bagian dari upaya preventif terhadap penanggulangan kejahatan adalah dengan program Jaksa Menyapa.

Program Jaksa Menyapa ini merupakan program yang dibuat oleh Kejaksaan untuk meningkatkan kesadaran hukum bagi masyarakat melalui dialog interaktif saluran radio RRI berskala nasional yang menjangkau masyarakat hingga daerah terpencil dengan harapan dapat memberikan pencerahan dan pendidikan guna menumbuhkan kesadaran hukum secara lebih luas dan mudah. Sedangkan untuk upaya represif yang dilakukan oleh Kejaksaan yang pertama sama halnya dengan Kepolisian yaitu mengutamakan Diversi. Namun sesuai dengan ketentuan Pasal 7 Ayat (2) UU SPPA, Diversi hanya bisa dilakukan apabila ancaman pidana atas tindak pidana yang dilakukan dibawah 7 (tujuh) tahun, sehingga dalam kasus pembunuhan berencana yang dilakukan oleh anak tidak bisa dilakukan Diversi. Kemudian upaya yang dilakukan selanjutnya adalah tetap melanjutkan proses hukumnya dan melimpahkan perkara ke Pengadilan namun sesuai dengan acara peradilan pidana anak. Jaksa sebagai Penuntut Umum Anak dalam prosesnya wajib memberikan perlindungan khusus bagi Anak yang diperiksa

${ }^{38}$ Barda Nawawi Arief, Bunga Rampai Kebijakan Hukum Pidana: Perkembangan Penyusunan Konsep KUHP Baru, Jakarta: Kencana, 2008, hlm. 24. 
karena tindak pidana yang dilakukannya dalam situasi darurat, memperhatikan kepentingan terbaik bagi Anak dan mengusahakan suasana kekeluargaan tetap terpelihara, wajib merahasiakan identitas Anak korban dalam pemberitaan di media, Anak harus difasilitasi bantuan hukum dan didampingi oleh Pembimbing Kemasyarakatan atau Pendamping lain sesuai dengan ketentuan Undang-Undang, serta di dalam proses persidangannya tidak memakai toga atau atribut kedinasan. Hal-hal tersebut diatas sesuai dengan penjelasan Bab III tentang Acara Peradilan Pidana Anak UU No. 11 Tahun 2012 tentang SPPA.

Selanjutnya menurut Dodik Setio Wijayanto Hakim Pengadilan Negeri Kalianda, upaya yang dilakukan oleh Pengadilan melalui Hakim yang bertugas dalam menanggulangi kejahatan pembunuhan berencana oleh anak terhadap anak adalah dengan upaya represif yaitu memberikan putusan yang seadil-adilnya berdasarkan pada fakta-fakta yang terjadi di dalam persidangan seperti latar belakang atau motif Anak sebagai pelaku tersebut melakukan tindak pidana, rekam jejak dalam melakukan kejahatan, peran di dalam kejahatan, tingkat pemahaman terhadap kejahatan yang dilakukan, cara melakukan tindak pidana dan juga jumlah barang bukti yang ada. Dalam prosesnya Hakim harus bisa memberikan teladan dalam menjalankan penegakan hukum, hal ini merupakan tugas peradilan sebagai pelaksana hukum dan lembaga pencari keadilan termasuk dalam mengadili tindak pidana yang dilakukan oleh Anak. Selanjutnya beliau menambahkan bahwa dalam menjatuhkan hukuman berupa pidana terhadap anak harus tepat dan jelas ketentuan mana yang dilanggar, serta dimana tempat anak sebagai pelaku tersebut menjalankan hukuman. Tujuan seorang hakim dalam menjatuhkan sanksi berupa pidana terhadap anak yang melakukan kejahatan khususnya pembunuhan berencana adalah agar menyadari kesalahan yang telah diperbuat dan memiliki perasaan empati sehingga tidak akan mengulangi kembali kejahatannya, baik kejahatan yang sama ataupun kejahatankejahatan lainnya.

\section{Penutup}

Berdasarkan hasil penelitian dan pembahasan tersebut di atas, penulis menganalisis:

1) Faktor penyebab terjadinya kejahatan pembunuhan berencana dengan pelaku dan korban anak yaitu:

a. Rendahnya tingkat pendidikan dan nilai-nilai spiritual;

b. Lingkungan yang tidak bersahabat (Keluarga, Sekolah dan Masyarakat);

c. Perkembangan teknologi yang sangat pesat;

d. Kemampuan ekonomi yang rendah;

2) Upaya dalam menanggulangi kejahatan pembunuhan berencana dengan pelaku dan korban anak yaitu:

a. Kebijakan yang sifatnya preventif, yakni upaya yang sifatnya lebih mencegah suatu tindak kejahatan. Upaya tersebut antara lain melakukan razia berupa senjata tajam, pengecekan identitas di tempat hiburan malam, melakukan penyuluhan hukum ke sekolah-sekolah serta penyuluhan hukum berupa dialog interaktif melalui media elektronik radio. Upaya ini adalah upaya yang dilakukan dari pihak Kepolisian, Kejaksaan dan semua masyarakat serta Pemerintah untuk bersama-sama mengambil bagian dalam pencegahan tindak kejahatan pembunuhan berencana khususnya yang dilakukan oleh anak-anak dibawah umur.

b. Kebijakan yang sifatnya represif, yakni upaya yang dilakukan setelah terjadinya suatu kejahatan. Kebijakan ini merupakan suatu bentuk upaya yang menitikberatkan pada proses peradilan sesuai dengan ketentuan yang tertera di dalam UU No. 11 tahun 2012 tentang SPPA yang bertujuan agar anak yang berhadapan dengan hukum tersebut mengerti akan kesalahan yang telah diperbuat sehingga tidak akan mengulangi kembali kejahatan yang dilakukannya melainkan menjadi lebih baik lagi. Aparat penegak hukum yakni Kepolisian, 
Kejaksaan, Pengadilan dan Pemasyarakatan merupakan bagian yang terlibat dalam proses kebijakan penanggulangan ini.

\section{Daftar Pustaka}

A. Buku

Alam, A. S., S.H., M.H dan Ilyas, Amir. S.H., M.H. 2018. Kriminologi Suatu Pengantar, Jakarta: Kencana.

Arief, Barda Nawawi. 2008. Masalah Penegakan Hukum dan Kebijakan Hukum Pidana dalam Penanggulangan Kejahatan, Jakarta: Kencana.

Arief, Barda Nawawi. 2008. Bunga Rampai Kebijakan Hukum Pidana: Perkembangan Penyusunan Konsep KUHP Baru, Jakarta: Kencana.

Djamali, R. Abdoel. 2019. Pengantar Hukum Indonesia, Depok: PT. RajaGrafindo Persada.

Hagan, Frank E. 2013. Pengantar Kriminologi, Jakarta: Kencana.

Mustofa, Muhammad. 2013. Metodologi Penelitian Kriminologi. Jakarta: Kencana.

Wiyoni R. 2018. Sistem Peradilan Pidana Anak, Jakarta: Sinar Grafika.

Santoso, Topo dan Zulva, Eva Achjani. 2011. Kriminologi. Jakarta: RajaGrafindo Persada.

B. Jurnal

Ardian Fikri, "Analisis Yuridis Terhadap Tindak Pidana Pembunuhan Berencana Yang Dilakukan Oleh Anak Dibawah Umur Menurut Undang-Undang Nomor 11 Tahun 2012 Tentang Sistem Peradilan Anak." Jurnal Abdi Ilmu, Vol. 1 No. 1, Juni 2018: 158-168, http://jurnal.pancabudi.ac.id/index.php/abdiilmu/article/view/388.

Ayu, Gusti, Novira Santi, Ni Putu, Rai Yuliartini, Dewa Gede, and Sudika Mangku. Perlindungan Hukum Terhadap Korban Tindak Pidana Penyalahgunaan Narkotika Di Kabupaten Buleleng," Jurnal Komunitas Yustitia, vol. 2, No. 1, February 28, 2019: 1-11, https://ejournal.undiksha.ac.id/index.php/jatayu/article/view/23924.

Buluran, Jesica Ribka. Penerapan Sanksi Pidana Terhadap Pelaku Kejahatan Mutilasi Menurut Pasal 340 Kuhp," LEX ET SOCIETATIS, vol. 5, No. 7, December 5, 2017:127-133, https://ejournal.unsrat.ac.id/index.php/lexetsocietatis/article/view/18098.

Djesi Ariani, "Pertanggungjawaban Pelaku Tindak Pidana Pembunuhan Berencana Yang Dilakukan Oleh Anak (Studi Putusan Pengadilan Negeri Nomor 16/Pid.SusAnak/2016/PN.Cbn)." Jurnal Hukum Kaidah: Media Komunikasi Dan Informasi Hukum Dan $\begin{array}{llllll}\text { Masyarakat, } & \text { Vol. } & 19, & \text { No. 2020: }\end{array}$ https://jurnal.uisu.ac.id/index.php/jhk/article/view/2334/1571.

Hardiyanto, Sigit, Elfi Syahri Romadhona, "Remaja Dan Perilaku Menyimpang (Studi Kasus Remaja Di Kota Padangsidimpuan)." Jurnal Interaksi : Jurnal Ilmu Komunikasi. Vol. 2, March 13, 2018: 23-32, http://jurnal.umsu.ac.id/index.php/interaksi/article/view/1785.

Intan, Eka, Putri Lembaga, Konsultan Bantuan, and Hukum Intan. "Begal Anak; Pemenuhan Hak Dan Lembaga Pembinaan Khusus Anak Kelas II A Bandar Lampung Fulfillment Of The Rights Of The Child In The Class Ii Special Child Coaching Institution In Bandar Lampung." Cepalo, Vol. 2, no. 2, September 12, 2018: 45-84. https://doi.org/10.25041/cepalo.v2no2.1764.

Shofwatal Qolbiyyah, "Kenakalan Remaja (Analisis Tentang Faktor Penyebab Dan Solusinya Dalam Perspektif Pendidikan Agama Islam)." Sumbula: Jurnal Studi Keagamaan, Sosial Dan Budaya, Vol. 2, No. 1, Januari-Juni 2017:493-512, http://ejournal.kopertais4.or.id/mataraman/index.php/sumbula/article/view/2984.

Maftukh Alifah, Arinal, Nanik Prihartanti, dan Imron Rosyidi,. "Dinamika Psikologis Narapidana Anak Pelaku Pembunuhan: Studi Kasus Di Lapas Anak Kutoarjo.” Indigenous: Jurnal Ilmiah Psikologi, Vol. 13, no. 2, October 12, 2016: 9-18, http://journals.ums.ac.id/index.php/indigenous/article/view/2600.

Mandagie, Anselmus S. J. "Proses Hukum Tindak Pidana Pembunuhan Yang Dilakukan Oleh Anak Dibawah Umur Ditinjau Dari Undang-Undang Nomor 11 Tahun 2012 Tentang Sistem 
Peradilan Pidana Anak." LEX CRIMEN. Vol. 9, May 18, 2020: 53-62, https://ejournal.unsrat.ac.id/index.php/lexcrimen/article/view/28552.

Maharani, "Manusia Sebagai Homo Economicus: Refleksi Atas Kasus-Kasus Kejahatan Di Indonesia." Jurnal Filsafat, Vol. 26, No. 1, Februari 2016: 31-52, https://dev.jurnal.ugm.ac.id/wisdom/article/view/12624/9083.

Mayo, Elton "Kajian Yuridis Terhadap Tindak Pidana Pembunuhan Yang Dilakukan Oleh Anak," Diponegoro Law Journal, vol. 3, No. 2, April 1, 2014: 1-12, http://ejournals1.undip.ac.id/index.php/dlr.

Nugraha, Agus Bambang. "Pembunuhan Berencana Oleh Anak Di Bawah Umur." JGK (Jurnal Guru Kita) 3, no. 2 (March 20, 2019): 144-57. https://jurnal.unimed.ac.id/2012/index.php/jgkp/article/view/14781.

Rismawati, Shinta Dewi. "Karakteristik Kejahatan Pembunuhan Dalam Konstalasi Relasi Gender." JURNAL PENELITIAN. Vol. 5, May 21, 2013: 1-11, https://doi.org/10.28918/JUPE.V5I1.237.

Syarifudin, Akhmad. "Tinjauan Yuridis Terhadap Tindak Pidana Pembunuhan Berencana." Dinamika: Jurnal Ilmiah Ilmu Hukum. Vol. 25, July 29, 2019: 1-5, http://www.riset.unisma.ac.id/index.php/jdh/article/view/4210.

Syamsiar Arief, "Tinjauan Yuridis Terhadap Tindak Pidana Pembunuhan Berencana Yang Dilakukan Oleh Anak," Petitum, Vol. 4, No. 1 (1 April 2016): 65-72, https://uit.ejournal.id/JPetitum/article/view/451/322.

C. Undang-Undang

Undang-Undang Dasar 1945.

Undang-Undang Nomor 3 tahun 1997 tentang Pengadilan Anak.

Undang-Undang Nomor 11 Tahun 2012 tentang Sistem Peradilan Pidana Anak.

Peraturan Pemerintah Nomor 65 tahun 2015 tentang Pelaksanaan Diversi dan Penanganan Anak Yang Belum 12 (dua belas) Tahun 2015. 
